\title{
Penyuluhan dan Pelatihan Pembuatan Nuget, Bakso Daging Ayam Petelur Afkir Kombinasi Rumput Laut Pada Kelompok Ibu-Ibu Kader Posyandu "Mawar" Perumahan Barat Dusun Karangduren Desa Jati)
}

\author{
Sri Sukaryani*1, Engkus Ainul Yakin², Catur Suci Purwati ${ }^{3}$ \\ 1,2,3 Program Studi Peternakan, Fakultas Pertanian, Universitas Veteran Bangun Nusantara \\ *e-mail: srisukaryani@gmail.com ${ }^{1}$,engkus_ainul@yahoo.com ${ }^{2}{ }_{\text {suci catur@gmail.com }}^{3}$
}

\begin{abstract}
Abstrak
Tujuan kegiatan Pengabdian kepada Masyarakat adalah untuk memberikan pengetahuan dan ketrampilan tentang pembuatan nugget dan bakso daging ayam petelur afkir yang dikombinasikan dengan rumput laut kepada kelompok ibu-ibu kader Posyandu "Mawar" Perumahan Barat Dusun Karangduren Desa Jati. Target kegiatan pengabdian ini adalah terjadinya peningkatan pengetahuan dan ketrampilan terhadap peserta kegiatan pengabdian ini. Metode yang diterapkan meliputi beberapa tahapan, yaitu tahap pertama melaksanakan pelatihan in class; tahap kedua melakukan praktek; tahap ketiga adalah monitoring dan evaluasi. Kegiatan pengabdian ini dalam pelaksanaan diawali dengan sosialisasi program dilanjutkan dengan memberikan pre test terhadap ibu-ibu kader posyandu sebagai dengan tujuan untuk mengetahui tingkat pengetahuan dan ketrampilannya sebelum menerima program kegiatan ini. Peserta dalam mengikuti pelatihan in class dan praktek pembuatan nugget dan bakso secara teori sangat antusias dan semangat serta bisa saling bekerjasama baik antar sesama peserta maupun antara peserta dan tim pengabdi. Setelah kegiatan praktek, peserta diberikan post test hal ini untuk mengetahui adanya peningkatan pengetahuan dan ketrampilan dari peserta. Nilai pre test rata-rata 41.92 dan rata-rata nilai post test 82,30. Kesimpulan yang dapat diambil dari kegiatan ini adalah terjadi peningkatan pengetahuan dan ketrampilan pada ibu-ibu kader Posyandu Mawar peserta kegiatan pengabdian PMKBI ini sebesar $96,33 \%$.
\end{abstract}

Kata kunci: bakso, nuget, rumput laut

\begin{abstract}
The purpose of this Community Service activity is to provide knowledge and skills about making rejected layer chicken nuggets and meatballs combined with seaweed to a group of cadres of Posyandu "Mawar" West Housing, Karangduren Hamlet, Jati Village. The target of this service activity is to increase the knowledge and skills of the participants of this service activity. The method applied includes several stages, namely the first stage of implementing in-class training; the second stage is doing practice; the third stage is monitoring and evaluation. This service activity in the implementation begins with program socialization followed by giving a pre-test to posyandu cadres with the aim of knowing their level of knowledge and skills before accepting this activity program. Participants in participating in in-class training and the practice of making nuggets and meatballs are theoretically very enthusiastic and enthusiastic and can cooperate with each other both among participants and between participants and the service team. After the practical activity, participants were given a post test to determine the increase in the knowledge and skills of the participants. The average pre-test value was 41.92 and the post-test average was 82.30. The conclusion that can be drawn from this activity is that there is an increase in knowledge and skills of the Posyandu Mawar cadres participating in this PMKBI service activity of $96.33 \%$.
\end{abstract}

Keywords: meatballs, nuget, seaweed

\section{PENDAHULUAN}

Daging ayam merupakan bahan pangan yang banyak dikenal oleh masyarakat dari tingkat ekonomi rendah sampai golongan masyarakat yang berpengahasilan tinggi. Daging ayam merupakan bahan pangan yang mengandung nutrisi sangat lengkap yang dibutuhkan oleh manusia [3]. Kandungan nutrisi tersebut antara lain protein, lemak, karbohidrat, mineral dan vitamin [2]. Kandungan nutrisi daging ayam petelur afkir adalah protein 22,93\%, lemak 1,49\% [1]. 
Daging ayam petelur afkir merupakan daging ayam yang berasal dari ayam petelur afkir yang dipelihara dengan tujuan untuk menghasilkan daging, karena produksi telurnya sudah menurun [3]. Daging ayam petelur afkir ini teksturnya lebih keras jika dibandingkan dengan daging ayam broiler [4]. Keempukan daging ayam merupakan salah satu faktor yang akan menentukan daya terima konsumen terhadap daging ayam [5].

Sehubungan dengan hal tersebut, maka perlu dilakukan upaya untuk meningkatkan daya minat konsumen terhadap daging ayam petelur afkir, yaitu dengan membuat produk olahan berupa nugget daging ayam petelur afkir.

Desa Jati merupakan salah satu desa yang ada di kecamatan Jaten kabupaten Karanganyar. Wilayah Desa Jati secara keseluruhan sekitar 265.4700 Ha, dengan batas-batas wilayah sebagai berikut : Sebelah Utara adalah Desa Papahan, Sebelah Timur ditempati Kalurahan Jungke, Sebelah Selatan diduduki Desa Suruh kalang dan Sebelah Barat berbatasan dengan Desa Sapen, Kecamatan Mojolaban, Kab. Sukoharjo. Secara umum wilayah Desa Jati merupakan dataran rendah dengan ketinggian 100 meter dpl, suhu udara rata-rata mencapai 26 -27 derajad celcius dan curah hujan berkitar pada $33 \mathrm{Mm} / \mathrm{Th}$,

Desa Jati terdiri dari 4 wilayah kerja dusun yaitu : Dusun Banaran yang meliputi RW-I yang mengkoordinir 8 RT yang terdiri dari 3 Dukuh dan 2 Perumahan sebagai berikut : 1) Dukuh Ocak-Acik terbagi menjadi 2 RT yaitu RT -01 dan RT-02; 2) Dukuh Pundungrejo terdiri dari 2 RT yaitu RT-03 dan RT -04; 3) Dukuh Banaran - Mlori terbagi menjadi 2 RT yaitu RT -05 dan RT -06; 4) Perumahan Puri Taman Sari I adalah RT -07 dan 5) Perum Taman Sari II adalah RT -08.

Dusun Dukuh meliputi 2 wilayah kerja RW terdiri dari 2 dukuh yakni : 1) RW-II berada di Dk. Dukuh terbagi menjadi RT-01, RT-02, RT-03 dan RT-04., 2) RW-III terbagi menjadi 2 Dukuh yaitu : a) Dukuh Sorobaon adalah wilayah kerja RT-01, b) Dukuh Gotanon meliputi RT02, RT-03, RT-04. Dusun Karangduren meliputi RW-IV, RW-V dan RW-VI, dengan 2 Dukuh dan 2 Perumahan, yaitu : 1) Dukuh Jumok adalah wilayah kerja RT-01 dalam RW-IV; 2) Dukuh Karangsono adalah wilayah Kerja RT-02 dalam RW-IV; 3) Dukuh Karangduren meliputi Wilayah Kerja RT-03, RT-04, RT-05 dalam RW-IV; 4) Perumahan Barat adalah wilayah kerja RW-V terdiri dari 4 RT; 5) Perumahan UNS Timur adalah wilayah kerja RW-VI terdiri dari 5 RT.

Posyandu "Mawar" adalah salah satu Posyandu yang ada di dusun Karangduren, tepatnya Posyandu tersebut berada di wilayah Perumahan Barat RW V. Posyandu "Mawar" menempati tempat kegiatan di Wisma Darusalam Perumahan di Jl Pembangunan II no.54. Posyandu "Mawar" berdiri sejak tahun 1990 dengan ketua Ibu Maria Lesmono beranggotakan 8 orang kader. Pada saat awal berdirinya, Posyandu ini kegiatannya terbatas hanya pada penimbangan balita namun seiring dengan berjalannya waktu Posyandu ini sudah mengalami perkembangan dengan mengembangkan Posyandu Lansia sejak yahun 2002. Posyandu "Mawar" saat ini dipimpin oleh ibu Ika Agustina Gunawan Wibisono, dibantu oleh seorang sekretaris yang bernama ibu Yosika Arif Kamal. Kelompok Kader Posyandu sebanyak 8 orang yang merupakan perwakilan dari 4 wilayah RT. Mawar melakukan kegiatan penimbangan balita secara rutin setiap bulan sekali yaitu tiap tanggal 14, begitu juga posyandu lansia juga berjalan kegiatannya setiap akhir bulan secara rutin tiap bulan, dengan pemeriksaan tekanan darah dan penimbangan berat badan. Pemeriksaan kesehatan bagi lansia terutama pemeriksaan kadar gula darah, cholesterol dan asam urat juga dilakukan setiap 3 bulan sekali pad akhir bulan bekerjasama dengan RS Jati Husada Karanganyar. Kelompok Kader Posyandu Mawar yang berjumlah 8 orang ini semuanya sebagai ibu rumah tangga, tanpa pekerjaan tetap maupun sambilan sehingga penghasilannya hanya ditopang dari penghasilan para suami sebagai kepala keluarga.

Setiap melaksanakan kegiatan penimbangan berat badan balita maupun pelaksanaan kegiatan posyandu lansia, Posyandu ini selalu menyediakan makanan baik yang ditujukan untuk anak balita maupun untuk para orang tua lansia yang datang mengikuti kegiatan Posyandu. Makanan yang disediakan bervariasi berupa makanan snack ataupun makanan sehat lainnya. Pengadaan makanan ini biasanya dengan membeli dari pedagang makanan dan kadangkala juga diadakan sendiri oleh kader. Untuk membuat menu makanan yang lebih variatif dan untuk memberikan penghasilan sendiri bagi para kader, maka tim Pengabdian Masyarakat dari Prodi Peternakan perlu memberikan kegiatan "Penyuluhan dan Pelatihan Pembuatan Nugget dan 
Bakso Daging Ayam Petelur Afkir kombinasi Rumput Laut Pada Kelompok Ibu-ibu Kader Posyandu Mawar Perumahan Barat Dusun Karangduren Desa Jati Kecamatan Jaten"

Berdasarkan observasi tim pengabdi terhadap kelompok Kader Posyandu Mawar, bahwa kelompok kader posyandu mawar $100 \%$ merupakan ibu rumah tangga dengan tingkat pendidikan sarjana $20 \%$ dan SMA $80 \%$,namun semuanya kader tersebut tidak mempunyai penghasilan sendiri dan hanya mengharapkan dari penghasilan suami, sehingga penghasilan keluarga berasal dari satu sumber. Kader posyandu tersebut membutuhkan suatu kegiatan yang bisa untuk mengisi waktu luang mereka sekaligus untuk mendapatkan penghasilan sehinga bisa meningkatkan kesejahteraan dan ekonomi keluarga.

Mereka setiap bulan juga harus mengadakan konsumsi untuk anak-anak balita dan orang tua lansia yang datang dalam kegiatan penimbangan berat badan dan pemeriksaan kesehatan bagi lansia. Mereka sering kebingungan untuk memilih menu sehat yang cocok buat balita maupun lansia. Bakso pada umumnya dalam pembuatannya dicampurkan dengan borak agar bakso menjadi kenyal, namun produk bakso tersebut kurang bagus untuk kesehatan. Berdasarkan hal tersebut maka perlu dicari alternatif bahan pengganti borak yang lebih sehat, dan bahan yang bisa dimanfaatkan sebagai pengganti borak adalah rumput laut. Rumput laut merupakan tumbuhan laut yang mempunyai kandungan protein sekitar $35 \%-47 \%$.

\section{METODE}

Berdasarkan kesepakatan dengan mitra atas permasalahan yang dihadapinya, maka solusi yang ditawarkan sebagai metode dalam pelaksanaan kegiatan pengabdian masyarakat ini antara lain adalah memberikan penyuluhan dan pelatihan tentang pembuatan nugget dan bakso daging ayam petelur afkir kombinasi rumput laut. Rencana tahapan kegiatan yang akan dilaksanakan meliputi :

1. Tahap I ( Penyuluhan )

Pada tahapan pertama ini dilakukan Penyuluhan / penyampaian materi tentang cara pembuatan nugget dan bakso daging ayam petelur afkir kombinasi rumput laut secara teori yang akan diikuti oleh seluruh ibu-ibu kader Posyandu Mawar. Sebelum penyuluhan akan dilakukan pre tes terhadap ibu-ibu peserta (ibu-ibu kader Posyandu Mawar)

2. Tahap II ( Praktek ) :

Tahap kedua ini, para peserta akan diberikan Pelatihan / Praktek pembuatan nugget dan bakso daging ayam petelur afkir kombinasi rumput laut. Kegiatan ini diharapkan diikuti oleh seluruh ibu-ibu kader Poasyandu Mawar

3. Tahap Evaluasi \& Monitoring

Tahapan evaluasi dan monitoring ini dilakukan dengan maksud untuk memantau dan mengevaluasi hasil kegiatan dari ibu-ibu kader Posyandu Mawar dalam melaksanakan produksi nugget dan bakso. Sudah sejauh mana mereka bisa memproduksi untuk memenuhi kebutuhan konsumsi keluarga dan untuk konsumsi saat kegiatan rutin Posyandu.

\section{HASIL DAN PEMBAHASAN}

Pengabdian Masyarakat (PMKBI) dengan mitra kelompok ibu-ibu kader Posyandu "Mawar" telah dilaksanakan dan kegiatannya berjalan dengan lancar. Kegiatan ini dilaksanakan di Wisma Darusalam Perumahan di Jl Pembangunan II no.54. yaitu rumah / tempat kegiatan rutin Posyandu Mawar.

Tahap pertama yang dilaksanakan dari kegiatan pengabdian ini adalah sosialisasi program pengabdian PMKBI dari tim pengabdi kepada seluruh anggota kelompok ibu-ibu kader Posyandu Mawar. Kegiatan ini diikuti oleh ibu-ibu kader Posyandu Mawar dan ibu ketua PKK Rt 03 di wilayah lokasi dari rumah tempat Posyandu Mawar. Kegiatan sosialisasi program ini dilaksanakan masih dalam keadaan PPKM yang ketat, sehubungan dengan hal tersebut maka tim pengabdi bersepakat dengan ketua Posyandu Mawar untuk mempersingkat waktu, maka dalam 
kegiatan sosialisasi program sekaligus dilakukan Pre Test guna mengetahui tingkat pengetahuan dan ketrampilan dari ibu-ibu kader Posyandu tentang pembuatan nugget \& bakso daging ayam rumput laut sebagai materi inti yang akan diberikan. Hasil nilai Pre Test dari peserta pelatihan rata-rata mendapatkan nilai / skor 41,92. Aktivitas peserta dalam mengikuti sosialisasi dan pre test terlihat pada gambar 1.
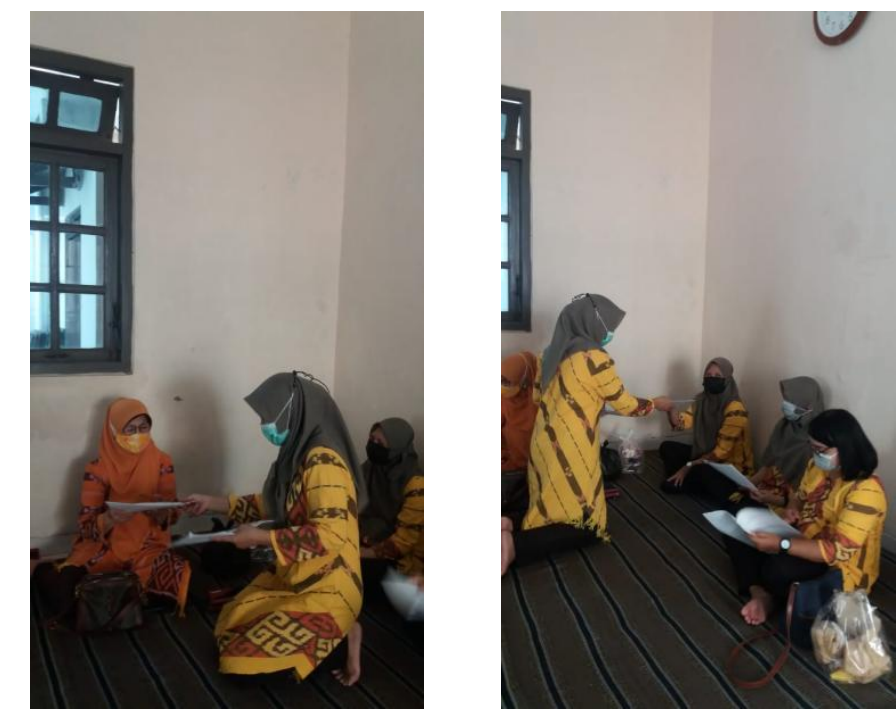

Gambar 1. Aktivitas Peserta Dalam Mengikuti Kegiatan Sosialiasi dan Pre Test

Tahap kedua Kegiatan penyuluhan / pelatihan in class, diikuti oleh seluruh anggota kader Posyandu dengan tetap menjaga prokes covid 19 tidak berkerumun dan memakai masker. Tim pengabdi memberikan materi teori membuat nugget ayam dan bakso dengan bahan dasar daging ayam petelur afkir yang dikombinasi dengan tepung rumput laut. Para ibu kader Posyandu aktif berinteraksi dalam pelatihan in class ini. Ada hubungan dua arah dalam kegiatan penyuluhan / ceramah / pelatihan in class ini. Banyak ibu-ibu kader yang terlibat dalam komunikasi dua arah ini, artinya banyak ibu-ibu yang memberikan respon positif atas materi yang disampaikan / diberikan oleh tim Pengabdi PMKBI. Aktivitas peserta dan tim pengabdi dalam kegiatan pelatihan in class terlihat pada gambar 2 .
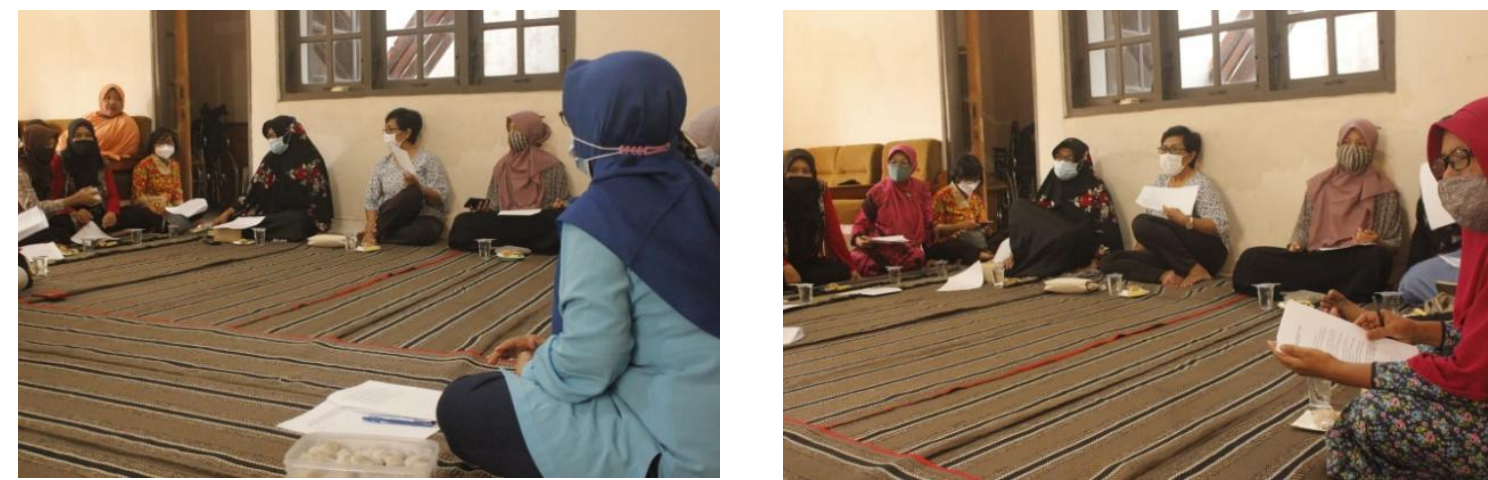

Gambar 2. Aktivitas Peserta dalam Kegiatan Pelatihan in class / penyampaian materi teori pembuatan Nugget dan Bakso Daging Ayam Petelur Afkir Kombinasi Rumput Laut

Tahap ketiga adalah kegiatan praktek membuat nugget dan bakso daging ayam petelur afkir yang dikombinasi rumput laut ini diikuti oleh ibu-ibu kader Posyandu Mawar dan tokoh masyarakat. Dalam kegiatan pengabdian ini selalu diikuti oleh tim satgas covid karena agar tidak terjadi kerumunan dan dalam menjalankan kegiatan pengabdian semua pihak bisa mentaati prokes covid 19. Pada kegiatan praktek membuat nugget dan bakso ini ibu-ibu kader Posyandu Mawar sangat antusias untuk melakukan praktek dan juga saling bertukar pengalaman dalam 
hal mengolah makanan. Namun disadari penuh oleh ibu-ibu kader posyandu bahwa kegiatan pengabdian dengan materi nugget dan bakso ayam petelur afkir yang dikombinasi dengan rumput baru kali ini mereka ketahui. Pada akhir kegiatan praktek,kemudian dilakukan Post Test terhadap ibu-ibu kader Posyandu peserta pelatihan. Nilai hasil Post Test peserta kegiatan pelatihan rata-rata adalah 82,30 . Aktivitas kegiatan praktek pembuatan nugget dan bakso bisa dilihat pada gambar 3 dan 4 .
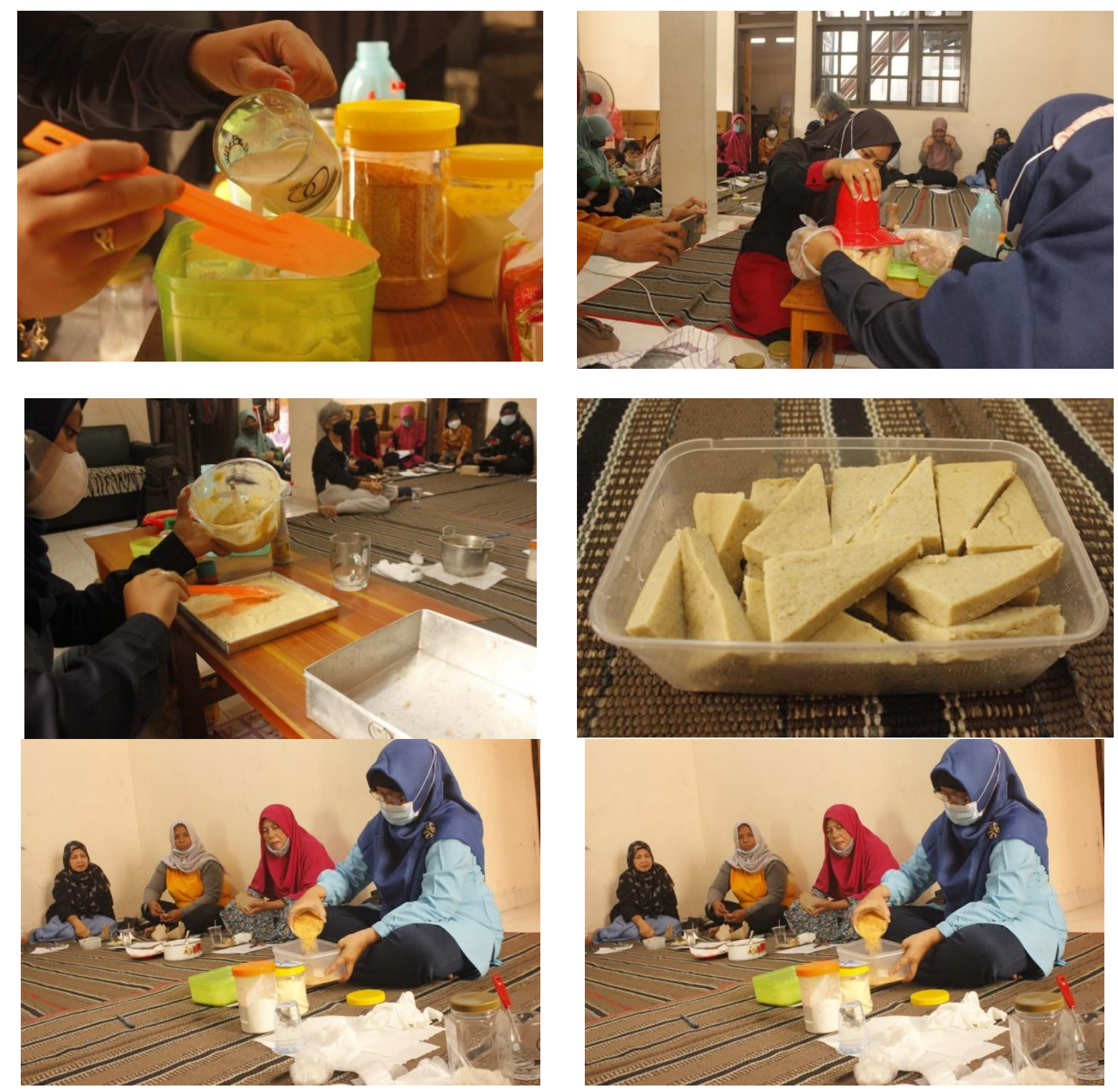

Gambar 3. Aktivitas Praktek Pembuatan Nugget Ayam Petelur Afkir Kombinasi Rumput Laut
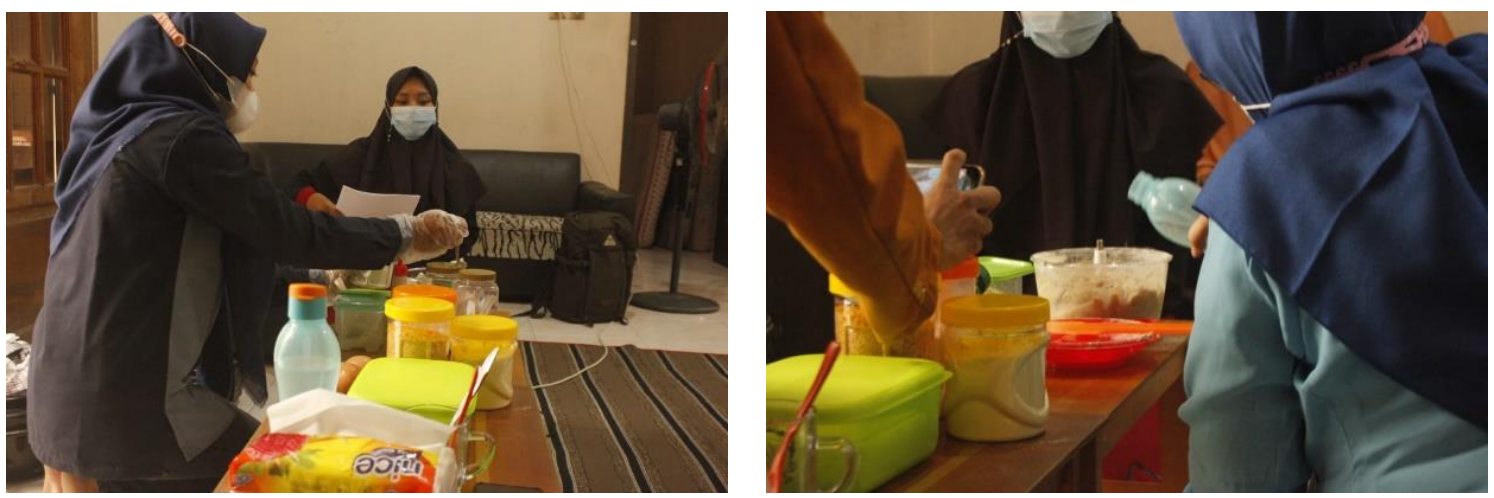

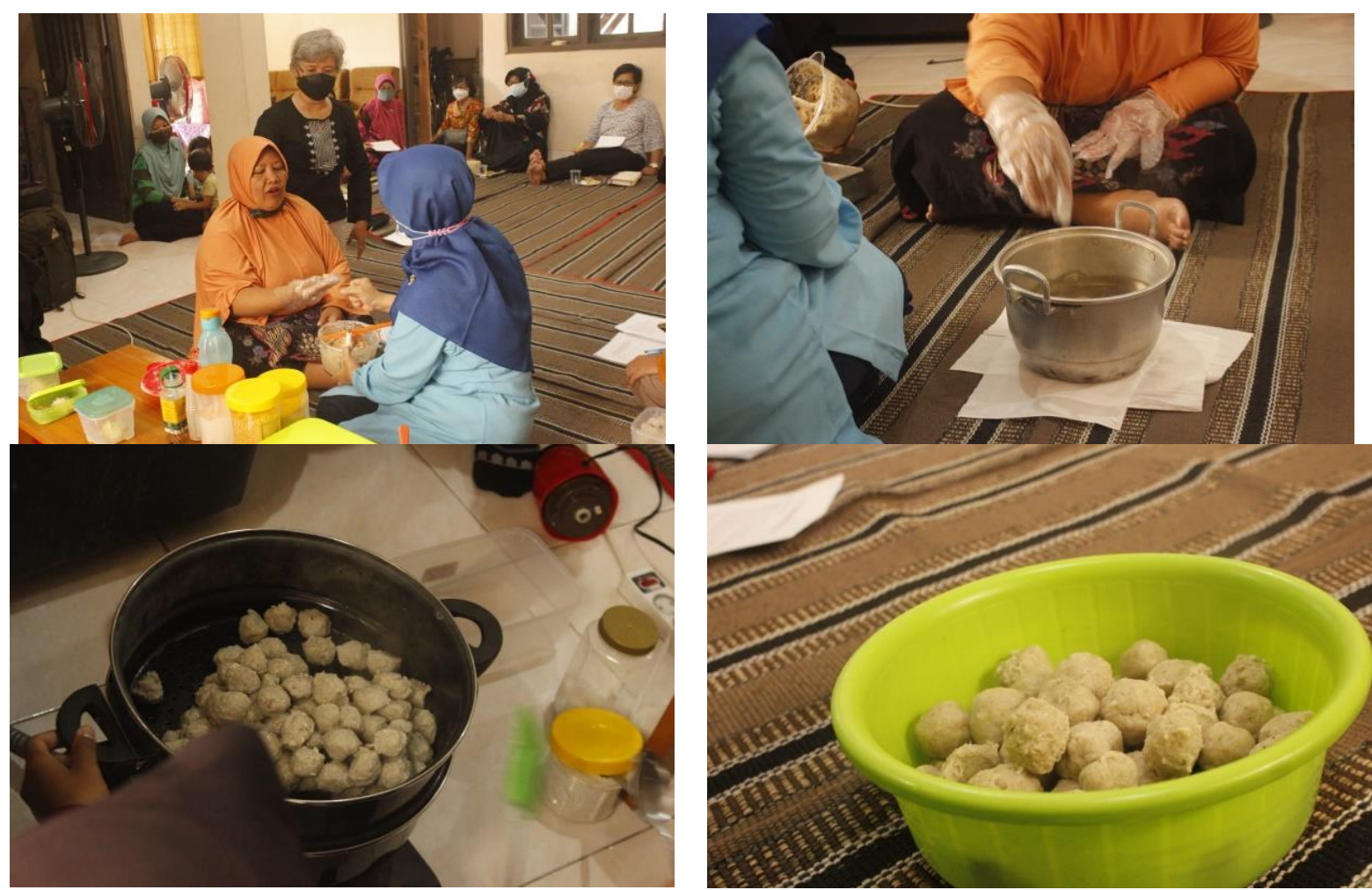

Gambar 4. Aktivitas Praktek Pembuatan Bakso Daging Ayam Petelur Afkir Kombinasi Rumput Laut

Rata-rata nilai pre test dan rata-rata nilai post test setelah diuji statistik menggunakan uji $T$ Test, didapatkan hasil bahwa antara pre test dan post test berbeda sangat nyata. Hasil uji statistik terlihat pada tabel 1.

Berdasarkan tabel 1, terlihat bahwa setelah dianalisis statistik dengan menggunakan uji $T$ Test, didapatkan bahwa post test berbeda sangat nyata terhadap pre test. Skore rata-rata pada saat pre test sebesar 41,92 dan pada saat post test sebesar 82,30. Berarti disini terjadi peningkatan pengetahuan dan ketrampilan pada seluruh peserta yang aktif mengikuti kegiatan pelatihan pembuatan nugget dan bakso sebesar $96,33 \%$

Tabel 1. Hasil T Test dari Pre Test dan Post Test Peserta Pelatihan Pembuatan Nuget dan Bakso Daging Ayam AFkir kombinasi Rumput Laut.

\begin{tabular}{lc}
\hline \multicolumn{1}{c}{ PERLAKUAN } & HASIL \\
\hline PRE TEST & $41,92 \mathrm{a}$ \\
POST TEST & $82,30 \mathrm{~b}$ \\
\hline rscript menunjukkan perbedaan yang sangat nyata
\end{tabular}

ab superscript menunjukkan perbedaan yang sangat nyata

\section{KESIMPULAN}

Kegiatan pengabdian PMKBI pada kelompok ibu-ibu kader "Posyandu Mawar" Perumahan Barat Dusun Karangduren Desa Jati, telah dilaksanakan dengan baik dan lancar serta dapat disimpulkan sebagai berikut :

1. Kegiatan penyuluhan dan pelatihan pembuatan nugget dan bakso daging ayam petelur afkir yang dikombinasi dengan tepung rumput laut telah terlaksana dengan baik dan lancer. Para peserta sangat aktif mengikuti kegiatan tersebut, baik pada kegiatan dalam bentuk ceramah / penyuluhan maupun pada saat praktek

2. Para peserta dalam mengikuti kegiatan praktek dan pendampingan produksi nugget dan bakso sangat antusias, serta saling bekerjasama dengan sinergis baik antar sesama peserta 
maupun antara peserta dan tim pengabdi PMKBI.

3. Terjadi peningkatan pengetahuan dan ketrampilan pada ibu-ibu kader Posyandu Mawar peserta kegiatan pengabdian PMKBI ini sebesar 96,33 \%.

\section{UCAPAN TERIMA KASIH}

Penulis ucapkan terima kasih yang telah memberikan bantuan dana hingga kegiatan pengabdian PMKBI ini berjalan dengan lancar. Penulis ucapkan terimakasih juga kepada ibu-ibu kelompok kade Posyandu Mawar.

\section{DAFTAR PUSTAKA}

[1] A. J. Marwansyah, I. A. Okarini., and I. N. S. Miwada, "Pengaruh Lama Perendaman Daging Ayam Petelur Afkir dalam Larutan. Peternakan Tropika," Journal of Tropical Animal Science, Vol. 7, No. 1, pp. 738 - 749, 2019.

[2] Nusdiani, Nuraini, and S. Adnan, "Kualitas Nugget Daging Ayam Petelur Afkir yang Disubstitusi Otak Sapi," JITRO, Vol.2, No.1, 2015.

[3] S. S. Harry, B. Sabtu, G. E. M. Malelak, "Kualitas Dendeng Giling Ayam Afkir yang Diberi Campuran Jantung Pisang dan Kelapa Parut," Journal of Tropical Animal Science and Technology, Vol. 1, No. 1, 2019.

[4] E. Wulandari, L. Suryaningsih, A. Pratama, D. S. Putra and N. Runtini, "Karakteristik Fisik, Kimia dan Nilai Kesukaan Nugget Ayam dengan Penambahan Pasta Tomat," Jurnal Ilmu Ternak, Vol. 16, No. 2, 2016.

[5] A. R. Yolanda, S.E. Siswosubroto, F.Ratulangi, J.E.G Rompis, "Sifat Organoleptik Nuget Ayam yang Menggunakan Tepung Kedelai Sebagai Penggantian Sebagian Daging," Jurnal Zootek ("Zootek" Journal), Vol. 38, No. 1 pp. 131-141, 2018, doi: https://doi.org/10.24198/jit.v16i2.11582. 